\title{
Description of the pupa of Cnemida retusa (Fabricius, 1801) (Melolonthidae: Rutelinae)
}

\author{
Matheus Bento ${ }^{1,3}$, Juares Fuhrmann² \& Marcus Vinícius Oliveira Bevilaqua ${ }^{1,4}$ \\ ${ }^{1}$ Instituto Nacional de Pesquisas da Amazônia (INPA), Coordenação de Biodiversidade (CBI0). Manaus, AM, Brasil. \\ ${ }^{2}$ Universidade de São Paulo (USP), Museu de Zoologia (MZUSP). ORCID: 0000-0002-1617-254X. E-mail: jufuhrmann@gmail.com \\ 3 E-mail: mabent02008@gmail.com (corresponding author) \\ ${ }^{4}$ ORCID: 0000-0003-2863-5115. E-mail: marcusbevilaqua@gmail.com
}

\begin{abstract}
Pupae of chafer beetle (Melolonthidae) Cnemida retusa (Fabricius, 1801) (Rutelinae, Rutelini) were collected in October and November of 2017 in a decaying log at Reserva Florestal Adolpho Ducke, Manaus, Amazonas, Brazil, and are described and illustrated. The pupa description is the first to the genus and a key to known pupae of Rutelini is added.
\end{abstract}

Key-Words. Chafers; Neotropical; Scarabaeoidea; White grub.

\section{INTRODUCTION}

The Neotropical genus Cnemida Kirby, 1827 (Melolonthidae: Rutelinae: Rutelini) includes 8 species and is identified by the convex body; pronotum longer than wide with a hexagonal shape and posterior margin 3-emargined; robust hind femur; mesepimeron exposed in dorsal view; usually with body color dark and average size of $1 \mathrm{~cm}$ (Kirby, 1827; Jameson, 1996). The adults are found on flowers and vegetation (Jameson, 1996). Kirby (1827) related adults covered by "farina" of flowers throughout the cuticular surface, and noted that all species of this genus were collected with some "farinaceous substance" from the plants they frequent, most likely for food.

Regarding genus immatures, the larvae are found in rotting wood feeding on decomposing organic matter (Morón, 1979; Jameson, 1996). Ohaus (1909: 126) reported larvae of C. retusa (Fabricius, 1801) in external parts of rotting wood in "San Antonio de Curaray", close to Curaray River margins, Ecuador, and described the larvae as: cranium reddish brown, slightly shiny and somewhat rugose; mandibles reddish yellow with incisor dark, left incisor 2-toothed, molar long and narrow $(0.6 \times 0.15 \mathrm{~mm})$; stipes dorsal stridulatory area bearing 9 teeth. In a genus review, Jameson (1996) described other Cnemida larvae, based in larvae of C. intermedia Bates, 1888. Cnemida pupae were unknown until the present work.

Cnemida retusa is the most commonly collected species within the genus, is widely distributed from northern South America to Argentina, and is similar to C. ephippiata Ohaus, 1912 and C. tristriata Jameson, 1996 (Jameson, 1996). Cnemida retusa is distinguished by the presence of brown or black elytra with orange or bronze spots, elytra with 4 striae and apicomedial elytral margin without strigulae extending up to the lateral disc striations (Jameson, 1996).

Larvae are relatively well known in Rutelini, but data on pupae are scarce (cf. Albertoni et al., 2014: table 1). Among about 650 species and 75 genera of American Rutelini (Jameson \& Morón, 2001), the pupae of 14 species are known (including present paper results): Chlorota cincticollis Blanchard, 1850, described by Jameson \& Morón (2001); Chrysophora chrysochlora (Latreille, 1811), described by Pardo-Locarno \& Morón (2007); Cnemida retusa, herein described; Heterosternus buprestoides Dupont, 1832, figured in Morón (1983); Lagochile emarginata (Gyllenhal, 1817), described by Albertoni et al. (2014); Macraspis aterrima Waterhouse, 1881 and M. chrysis (Linnaeus, 1764), described by Morón \& Paucar-Cabrera (2003); M. cincta (Drury, 1782), described by Vanin \& Costa (1980); M. festiva Burmeister, 1844, M. pseudochrysis Landin, 1956 and M. rufonitida Burmeister, 1844, described by Morón \& PaucarCabrera (2003); Paraheterosternus luedeckei (Becker, 1907), described by Morón \& Nogueira (2000); Rutela dorcyi (Olivier, 1789), described by Jameson (1997); Rutelisca durangoana Ohaus, 1905, described by Morón \& Deloya (1991).

The present article purposes to describe the pupae of Cnemida retusa. An identification key to the pupae of Rutelini is also given.

\section{MATERIAL AND METHODS}

During two expeditions carried out in the Adolpho Ducke Forest Reserve in Manaus munic- 
ipality, Amazonas State (AM), in October and November 2017, two adults (one male and one female) and three pupae of Cnemida retusa were found in the sapwood region of a decomposing log. The specimens were taken to the Laboratório de Sistemática e Ecologia de Coleoptera (LASEC) of the Instituto Nacional de Pesquisas da Amazônia (INPA). The pupae were fixed in PAMPEL solution (42\% distilled water, $44 \%$ alcohol $96^{\circ} \mathrm{GL}, 8 \%$ formalin and $5 \%$ glacial acetic acid) for 24 hours and then transferred to $80 \%$ alcohol.

The adults were identified using the key present in Jameson (1996) and compared with other previously identified specimens deposited in LASEC. The specific attribution of the pupae was performed by the association with adults collected and later identified by observation of diagnoses of teneral adults enclosed in pupal skin. The determination of male and female pupae was possible through the analysis of male and female genital ampulla (cf. Sousa et al., 2018).

Photographs were taken with a Leica DFC295 camera attached to a Leica M165C stereomicroscope and were processed using the Leica Application Suite (LAS) software version 4.1. The photographic illumination system follows Kawada \& Buffington (2016). The voucher specimens of this study were deposited in LASEC.

The terminology follows Sousa et al. (2018). Familiar group classification follows Cherman \& Morón (2014). The proposed identification key included here uses information provided by Albertoni et al. (2014), Jameson (1997), Jameson \& Morón (2001), Morón (1983), Morón \& Deloya (1991), Morón \& Nogueira (2000), Morón \& Paucar-Cabrera (2003), Pardo-Locarno \& Morón (2007) and Vanin \& Costa (1980).

\section{RESULTS}

\section{Pupae of Cnemida retusa (Fabricius, 1801) (Figs. 1-2)}

Specimens examined: Three pupae of C. retusa were collected together with two adults, one male and one female. The specimens are deposited at the LASEC with the following data: BRAZIL, Amazonas: Manaus, Reserva Florestal Adolpho Ducke, $02^{\circ} 55.800^{\prime} \mathrm{S}$, 59 $55.370^{\prime} \mathrm{W}$, 13.x.2017, decaying woods, M. Bento (collector), 1 teneral female adult, a male and a female pupae; same data but 30.x-03.xi.2017, 1 teneral male adult; 1 female pupa.

Pupa description: (Figs. 1-2). Body: length: $10.5 \mathrm{~mm}$ (male), $12.5 \mathrm{~mm}$ (female); greater width: $5.3 \mathrm{~mm}$ (male), $6.1 \mathrm{~mm}$ (female); body elongated, oval (Figs. 1A-C; 2A-C) and yellowish white. Body surface glabrous. Head: vertex visible dorsally; eyes partially covered by the anterior angles of pronotum and canthus; clypeus subsquare, clypeofrontal suture more evident laterally than medially, inconspicuous or weakly sinuous medially; labrum trapezoidal; mandibles subtriangular; maxillary and labial palps tubercle-like; labium conical, with a posterior projection toward the prosternal process; anten- na with three lobes: scape-pedicel, funicle and clava. Thorax: pronotum somewhat octagonal: anterior angles acute and produced over eyes, lateral and posterior angles slightly prominent, posterior margin slightly sinuate and with 2 small lobes posteriorly directed (Figs. 1A, 1D, 2A, 2D); surface with striations between anterior and posterior margins and between lateral margin and disc (Figs. 1D, 2D). Mesonotum posteriorly projected, medial length about two times longer than lateral length (between medial area and elytral theca basis), shorter than the pronotum medially. Metanotum posteriorly projected, projection shorter than the projection of mesonotum and partially covering the anterior margin of the abdominal tergite I. Prosternal process small tubercle-like (Fig. 1C). Pterothorax with ventral process short, large, with apex rounded, extended between mesocoxae. Elytral and wing thecae resting under the median legs in ventral view, partially covering the posterior legs; elytral thecae with 4 visible punctuated striations (Figs. 1D, 2D). Anterior legs hidden by the pronotum in dorsal view; meso- and metafemur-tibia articulations visible dorsally; meso- and metatibial apex with two unequal and weakly visible tubercle-like spurs. Abdomen: tergites II-VI with a pair of dorsolateral tubercles each; tergite VIII about 0,6 times longer than VII in the middle area; 5 pairs of well-defined dioneiform organs present between segments I-II, II-III, III-IV, IV-V and V-VI; tergite IX laterals ventrally folded, fold with 17 small spines (Figs. 1E, 2E). Spiracles: I covered by posterior wing thecae; I-IV with slightly sclerotized peritreme; V-VIII opening as cuticular invagination, VI-VIII prominent. Male terminalia (Fig. 1E): anterior genital ampulla with a central cross-marking and sinuous posterior margin medially; posterior genital ampulla rounded, with two lateral tubercles, apex with central cross-marking. Female terminalia (Fig. 2E): sternite IX with bilobed genital ampulla, longitudinally divided; sternite $X$ exposed, with two parallel lines in the posterior region and two subparallel diagonal lines in the anterior region.

Remarks: Among the known Rutelini pupae (see introduction), those of Cnemida are similar to those of Lagochile Hoffmannsegg, 1817 and Macraspis MacLeay, 1819 , because of the presence of a 3-emargined posterior margin of the pronotum. However, pupae of Cnemida are distinguished by (opposition to Lagochile and Macraspis): 1) pronotum with posteromedial lobe as wide as the mesonotum at the middle (narrower than the mesonotum at the middle); 2) pronotal disc surface with some striations (without striations); 3) mesonotum shorter than the pronotum medially (character similar in Lagochile; longer than the pronotum medially in Macraspis); 4) elytral thecae with 4 punctuated striae (without striae); 5) abdomen with 5 pairs of dioneiform organs (4 pairs); 6) abdominal spiracles II-IV with weakly sclerotized peritreme (strongly sclerotized peritreme); 7) abdominal tergite IX fold glabrous and with small spines (tergite IX fold setose and without spines); 8) meso-metaventrite process short, with apex slightly exceeded between mesocoxae (long and surpassing the mesocoxae). 


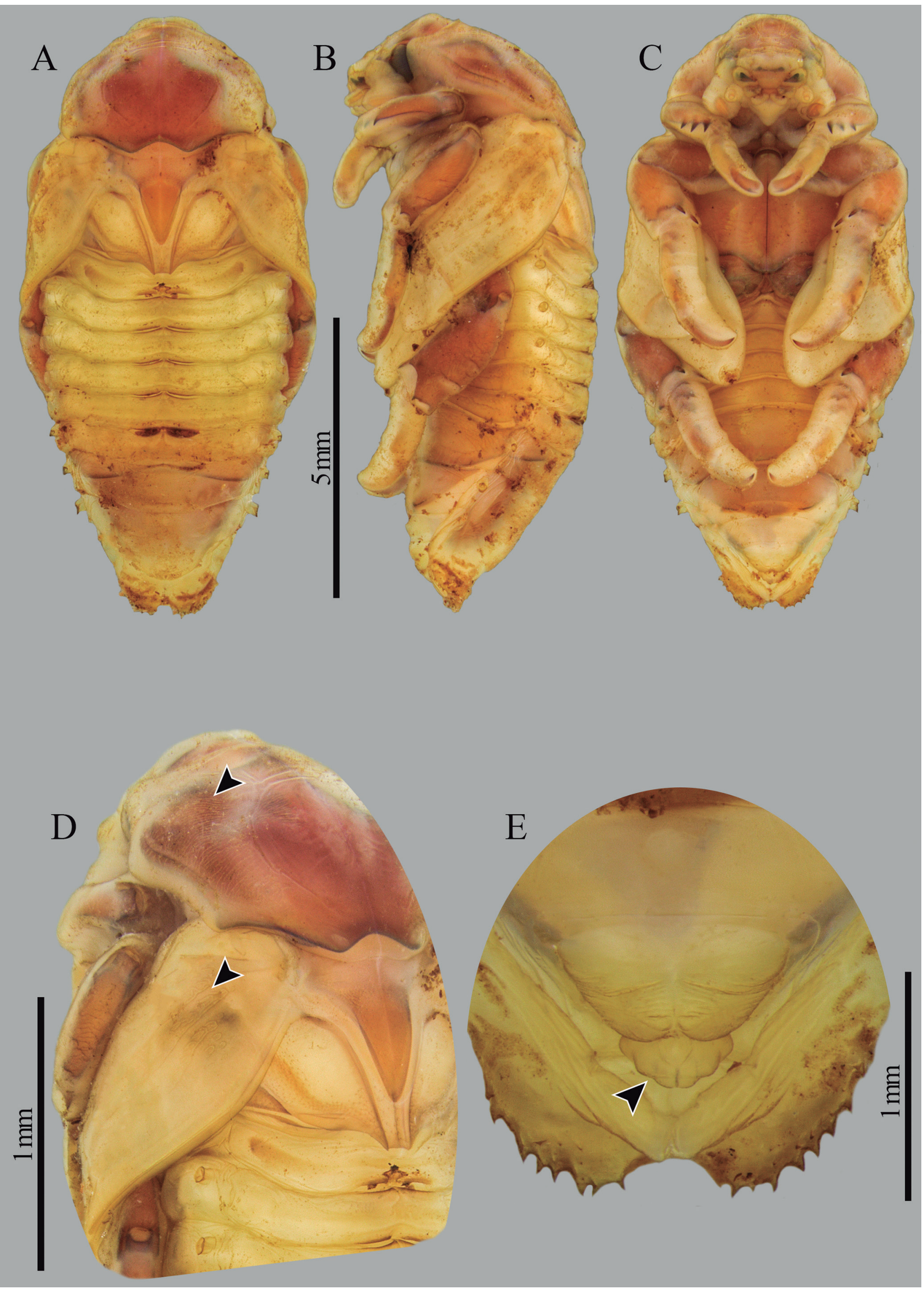

Figure 1. Male pupa of Cnemida retusa (Fabricius, 1801). (A) Dorsal. (B) Lateral. (C) Ventral. (D) Pronotum and elytral theca showing striation in dorsolateral view. (E) Ventral view of terminalia showing genital ampullae. 


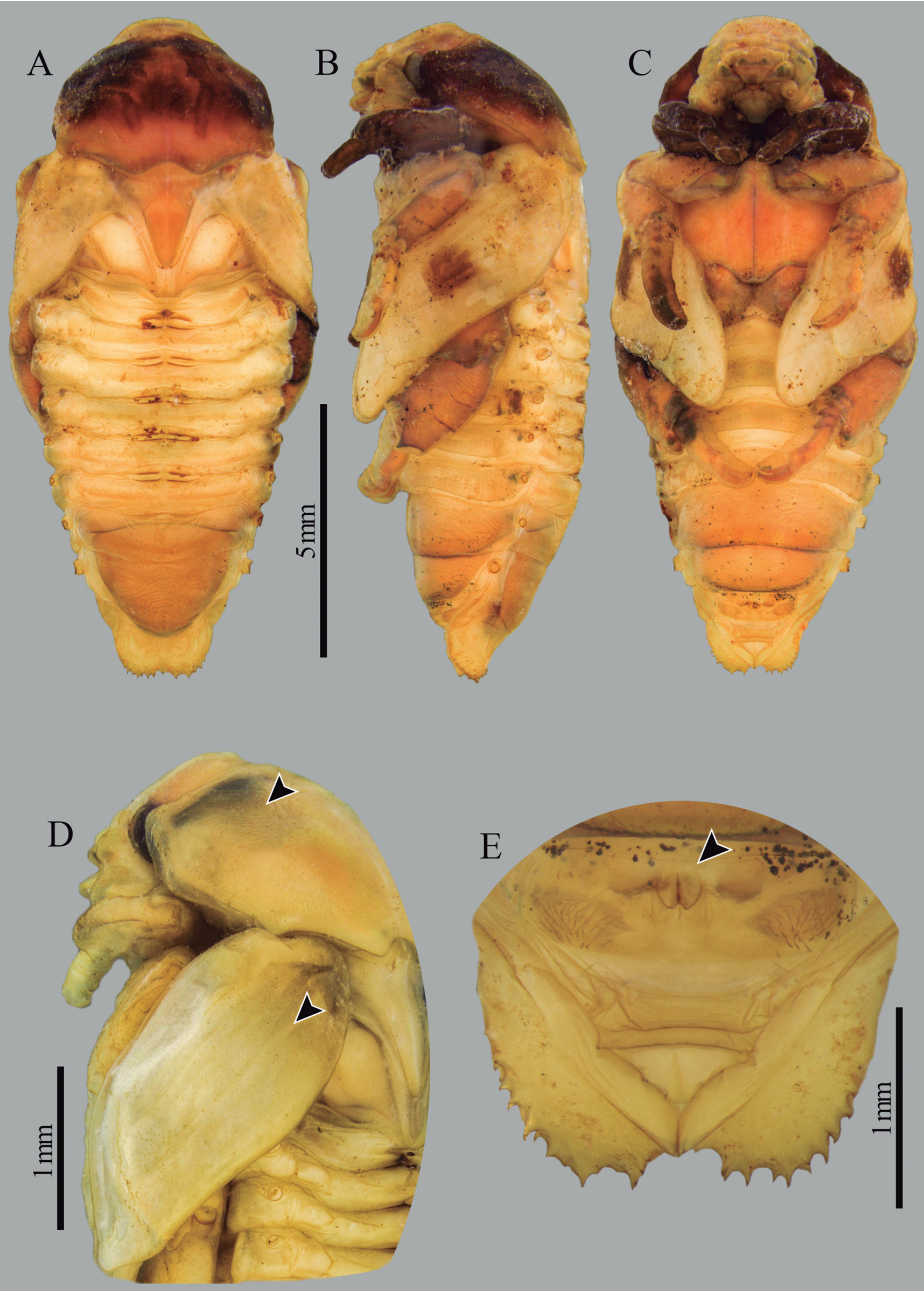

Figure 2. Female pupa of Cnemida retusa (Fabricius, 1801). (A) Dorsal. (B) Lateral. (C) Ventral. (D) Pronotum and elytral theca showing striation in dorsolateral view. (E) Ventral view of terminalia showing genital ampulla. 


\section{Key to genera and species of Rutelini based on known pupae}

Pupae of Rutelisca durangoana were described by Morón \& Deloya (1991) bearing 5 pair of dioneiform organs. More studies are needed to differentiate the pupae of this species from others. Pupae of Macraspis (step 7' and subsequent steps) were included but more studies are needed to clarify and check some diagnoses.

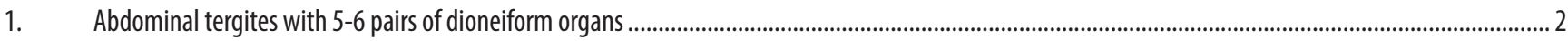

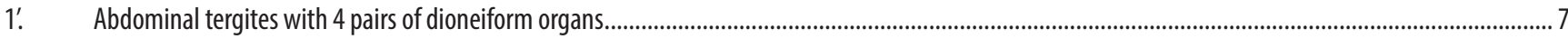

2. Abdominal tergite IX fold with small spines and without dense group of setae ....................................................................................... Cnemida retusa

2. $\quad$ Abdominal tergite IX fold without spines and with dense group of short setae ............................................................................................. 3

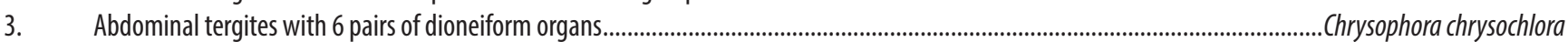

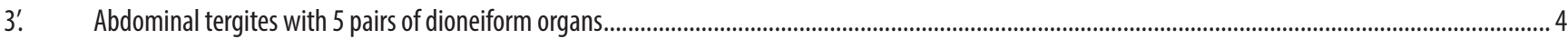

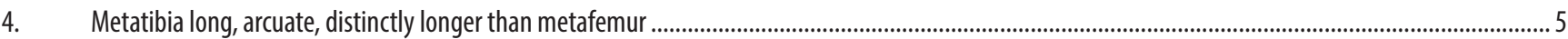

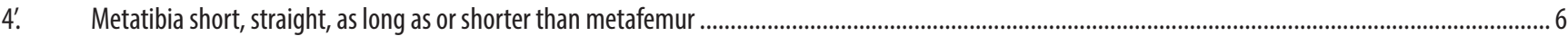

5. Metacoxa with short process on posterior margin; metafemur with short preapical process on posterior margin; metatibia with short medial process in inner margin ........ Paraheterosternus luedeckei Metacoxa, metafemur and metatibia without process ............................................................................................................. Heterosternus buprestoides Abdominal ventrite VI slightly longer than I-V combined ....................................................................................................................... Rutela dorcyi Abdominal ventrite VI much shorter than segments I-V combined .................................................................................................Chlorota cincticollis Mesonotum as long or almost as the pronotum and not reaching abdominal tergite I...................................................................... Lagochile emarginata

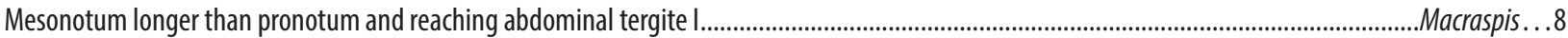

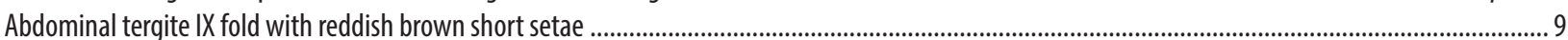

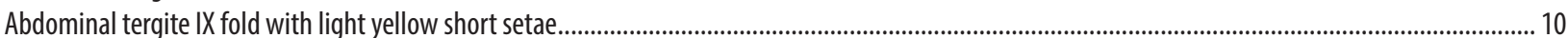
Frontoclypeal suture somewhat straight and medially indistinct ........................................................................................................................ (incta Frontoclypeal suture weakly sinuate and medially distinct (suture complete) .................................................................................................. chrysis

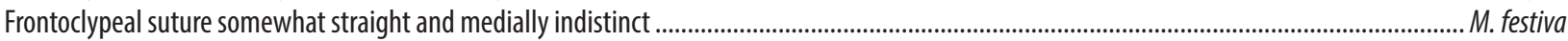

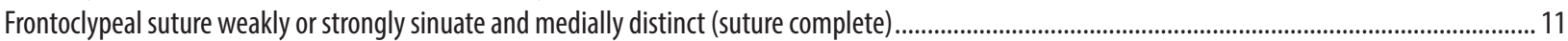
Abdominal sternites VIII-IX combined slightly longer than VII..................................................................................................................... p. pseudochrysis Abdominal sternites VIII-IX combined as long as or almost longer than VI-VII combined ....................................................................................... 12 Frontoclypeal suture weakly sinuate; pronotum semicircular shaped in dorsal view (cf. Morón \& Paucar-Cabrera, 2003: fig. 27) .......................... rufonitida Frontoclypeal suture evidently sinuate; pronotum somewhat transversal..................................................................................................... aterrima

\section{ACKNOWLEDGEMENTS}

We thank the INPA and LASEC for the infrastructure offered. Paschoal Coelho Grossi (UFRPE) is also thanked for the permission to study ruteline immature specimens deposited in the Coleção Entomológica da Universidade Federal Rural de Pernambuco (CERPE). To Conselho Nacional de Desenvolvimento Científico e Tecnológico (CNPq), for the financial support granted to the first author. JF thanks Sônia A. Casari (Museu de Zoologia da Universidade de São Paulo) for supervision. MVOB thanks Coordenação de Aperfeiçoamento de Pessoal de Nível Superior - CAPES for granting the scholarship by way of PROTAX 001/2015 "Estudos sistemáticos para as famílias Psephenidae, Scarabaeidae e Torridincolidae (Coleoptera: Polyphaga e Myxophaga) e análise filogenética do subgênero Ontherus (Scarabaeidae: Scarabaeinae): grupos taxonômicos negligenciados na Amazônia". The authors would like to thank the reviewers who proposed good contributions to enrich the present work.

\section{REFERENCES}

Albertoni, F.F.; Fuhrmann, J. \& Ide, S. 2014. Lagochile emarginata (Gyllenhal): morphology of immature and imago, and biological records (Coleoptera, Scarabaeidae, Rutelinae). Revista Brasileira de Entomologia, 58: 32-46. D0I
Cherman, M.A. \& Morón, M.A. 2014. Validación de la Familia Melolonthidae Leach, 1819 (Coleoptera: Scarabaeoidea). Acta Zoológica Mexicana (n.s.), 30: 201-220.

Jameson, M.L. 1996. Revision and phylogeny of the Neotropical genus Cnemida (Coleoptera: Scarabaeidae: Rutelinae). Insecta Mundi, 10: 285-315.

Jameson, M.L. 1997. Phylogenetic analysis of the subtribe Rutelina and revisions of the Rutela generic groups (Coleoptera: Scarabaeidae: Rutelini). Bulletin of the University of Nebraska State Museum, 14: 1-184.

Jameson, M.L. \& Morón, M.A. 2001. Descriptions of the larvae of Chlorota cincticollis Blanchard and Chasmodia collaris (Blanchard) (Scarabaeidae: Rutelinae: Rutelini) with a key to the larvae of the American genera of Rutelini. The Coleopterists Bulletin, 55: 385-396.

Kawada, R. \& Buffington, M.L. 2016. A Scalable and modular dome illumination system for scientific microphotography on a budget. PLOSONE, 11: 1-20. DOI

Kirby, W. 1827. A description of some new genera and species of petalocerous Coleoptera. The Zoological Journal, 3: 145-148.

Morón, M.A. 1979. Fauna de coleopteros lamelicornios de la estacion de biologia tropical, "Los Tuxtlas", Veracruz, UNAM. Mexico. Anales del Instituto Biología de la Universidad Nacional Autonoma de Mexico, Serie Zoologia, 50: 375-454.

Morón, M.A. 1983. A revision of the subtribe Heterosternina (Coleoptera, Melolonthidae, Rutelinae). Folia Entomológica Mexicana, 55: 31-101.

Morón, M.A. \& Deloya C. 1991. Los coleopteros lamelicornios de la Reserva de la Biosfera "La Michilia", Durango, Mexico. Folia Entomológica Mexicana, 81: 209-283. 
Morón, M.A. \& Nogueira, G. 2000. Third stage larva and pupa of Paraheterosternus luedeckei (Becker) (Coleoptera: Melolonthidae; Rutelinae). Journal of the Kansas Entomological Society, 73: 62-67.

Morón, M.A. \& Paucar-Cabrera, A. 2003. Larvae and pupae of species of the genus Macraspis (Coleoptera: Scarabaeidae: Rutelinae: Rutelini). The Canadian Entomologist, 135: 467-491.

Ohaus, F. 1909. Bericht über eine entomologische Studienreise in Südamerika. Stettiner Entomologische Zeitung, 70: 3-139.
Pardo-Locarno, L.C. \& Morón, M.A. 2007. Larva and pupa of Chrysophora chrysochlora (Coleoptera: Scarabaeidae: Rutelinae: Ruelini). The Canadian Entomologist, 139: 80-86.

Sousa, R.; Fuhrmann, J.; Kouklík, 0. \& Šípek, P. 2018. Immature stages of three species of Inca LePeletier \& Serville, 1828 (Coleoptera: Scarabaeidae: (etoniinae) and morphology of phytophagous scarab beetle pupa. Zootaxa, 4434: 65-88. D0I

Vanin, S.A. \& Costa, C. 1980. Larvae of Neotropical Coleoptera. III. Scarabaeidae, Rutelinae. Papéis Avulsos de Zoologia, 33: 275-282. 